\title{
Epidemiological Mapping of Hypertension, Diabetes Mellitus and Obesity among Menoufia Medical Students' Family Members
}

\author{
Hala M Gabr MD ${ }^{1}$, Reda A Ibraheem MD ${ }^{1}$, Zeinab A Kasemy MD', Shimaa S Soliman MD* 1 \\ ${ }^{1}$ Department of Public Health and Community Medicine-Faculty of Medicine,Menoufia \\ University
}

\begin{abstract}
:
Background: Hypertension (HT), type 2 diabetes mellitus (DM) and obesity are amongst the most common non-communicable chronic diseases in the developed and developing countries that have substantial economic burden. Objectives: To estimate the prevalence and describe the epidemiological mapping of hypertension, diabetes mellitus and obesity among Menoufia medical students' family members. Methods: A cross sectional study has been conducted on 13,782 family members of the students in the faculty of medicine, Menoufia University during the academic year 2018-2019. Participants were asked to complete a predesigned questionnaire including demographic profile (age, sex, and residence) and questions about hypertension, diabetes mellitus and obesity among their family members. Results: The prevalence rates of hypertension, diabetes and obesity were $12.3 \%, 7.05 \%$ and $11.7 \%$ respectively. Hypertension was more prevalent among males, older than 40 years and those living in urban areas, while diabetes was more prevalent among females, older than 40 years $(p<0.001)$ without association to residence. Elbagour, Tala and Shebin Elkom ranked the top 3 districts in Menoufia governorate to have hypertensive patients with $14.65 \%, 14.34 \%$ and $14.05 \%$ respectively. Diabetes mellitus was most prevalent in Ashmon (8.97), Berket Elsaba (8.10\%), Menouf (8.12\%) and ElShohadaa (8.02\%). For obesity, it was more prevalent in Quesina (17.4\%) and Sers Ellian (15.7\%) and less prevalent in EL-Bagour (7.2\%). Conclusion: Hypertension and obesity were more prevalent than diabetes in Menoufia governorate. Male gender was a risk factor for HT while female gender was a risk factor for DM and obesity. Age $>40 \mathrm{y}$ was a risk factor for all diseases being studied.
\end{abstract}

Key words: Diabetes, Family, hypertension, mapping obesity, Menoufia.

\begin{tabular}{|c|c|}
\hline Introduction: & factors for coronary heart disease, stroke, \\
\hline Hypertension (HT) and type 2 & end-stage renal failure, disability and \\
\hline Diabetes mellitus (DM) are among the & increased health-care costs. Although \\
\hline most common non-communicable & DM and HT are not among the top \\
\hline chronic diseases in developed and & leading causes of death like in the case \\
\hline $\begin{array}{l}\text { developing countries a } \\
\text { (1)They are the main }\end{array}$ & cancer and stroke, these two dis \\
\hline
\end{tabular}

*Corresponding author: E-mail: shaimaasoliman@med.menofia.edu.eg 
growing trends. ${ }^{(2)}$ Hypertension is a multifactorial disease, and it is related to heredity, diet, environment pollution, and other factors. $^{(3)}$

Twenty nine percent of the world's adult population are projected to have hypertension by the year 2025; therefore, prevention and management of hypertension have become a public health priority. $^{(4)}$

Diabetes is a fast-growing health problem in Egypt with a significant impact on morbidity, mortality, and health care resources. Currently, the prevalence of type 2 diabetes in Egypt is around $15.6 \%$ of all adults aged 20 to 79 years, which puts Egypt at the ninth rank in the world for the number of DM patients according to International Diabetes Federation (IDF).

The prevalence of DM in Egypt has almost tripled over the last 2 decades. This sharp rise could be attributed to either an increased pattern of traditional risk factors such as obesity and physical inactivity and change in eating pattern, in addition to increased exposure to environmental risk factors like pesticides and increased prevalence of chronic hepatitis C. ${ }^{(5)}$ The American Heart
Association considers diabetes as one of the six major controllable risk factors for cardiovascular disease. ${ }^{(6)}$

Epidemiological and clinical studies have shown that these diseases often cluster in individuals and in families. ${ }^{(7)}$ Several studies conducted in different ethnic groups showed a close association between HT and DM, where the prevalence of HT is significantly higher in the patients with non-insulin dependent DM. ${ }^{(8)}$ Obesity is associated with a greater number of metabolic complications including type 2 diabetes and hypertension. Insulin may elevate blood pressure by affecting renal sodium retention. Several epidemiologic studies showed that excess weight substantially increased the risk for hypertension.

Obesity is dramatically growing in Eastern Mediterranean Region including Egypt. It is a major risk factor for the development of type 2 diabetes. Underlying and possible inherited insulin resistance is compounded by the fact that obesity worsens insulin sensitivity. ${ }^{(9)}$ In low-income and middle-income countries (including Egypt), the estimated agestandardized death rates in the year 2005 for chronic diseases in 54\% higher for 
men and $86 \%$ higher for women than men and women in high-income countries.

An estimated US $\$ 84$ billion of economic production will be lost from chronic diseases (heart disease, stroke, and diabetes alone) if no actions are taken to reduce the risk of these diseases ${ }^{(10)}$. Because of the growing health and economic burden of chronic diseases in Egypt, and lack of information about the epidemiology of hypertension, DM, and obesity distribution, in an entire Egyptian governorate, the aim of this study was to estimate the prevalence and describe the epidemiological mapping of hypertension, diabetes mellitus and obesity among Menoufia medical students' family members.

\section{Methods:}

A cross-sectional study was carried out on Menoufia medical students and their families during the academic year 2018-2019. Menoufia faculty of medicine is located at Menoufia governorate in Egypt and accommodates nearly 3800 students from all over the governorate. The study system is distributed over 6 years. In our study, we invited all grades starting from second to sixth grade as a cluster sample (not including the first junior grade being unfamiliar with studying system and research objectives). A pre-designed selfadministered questionnaire addressing chronic diseases was distributed among the included students. The questionnaire included data about participants' demographic profile (age, sex and residence) and questions about complaining of diabetes mellitus, hypertension and obesity. A pilot study was conducted on 350 students $(\sim 10 \%)$ to test the students' response, validity of the questionnaire, clarity of the questions by students and their families, and to evaluate the efficacy of the questionnaire to be adjusted if need be. After exclusion of 550 students due to either incomplete questionnaire or refusal to participate, a total of 2442 questionnaires were valid to be included in the study with a response rate of $82 \%$. At last, the total number of the students' family members was 13,782 individuals with a range of 3-7 members per family. Those students are already distributed in the 10 districts of Menoufia Governorate. For affirming obesity, participants were asked to measure height and weight of themselves bare footed and without heavy clothes by an electronic 
scale (model no. HJKH-02, country: China, brand name: Sincoly). Weight was measured to the nearest $0.5 \mathrm{~kg}$. Height was measured to the nearest $0.1 \mathrm{~m}$. BMI (body mass index) was then calculated by dividing weight in $\mathrm{kg}$ by the square height in meters, body mass index above 30 was considered obese.

Ethical Considerations: Approval from the research and ethics committee of Menoufia faculty of medicine and an informed student's family assent were obtained after explanation of all aspects of the study and the right to withdraw at any time. The main outcome measures were the proportions (prevalence rates) of DM, HT and obesity among the families of Menoufia medical students.

Statistical analysis: Data were collected, tabulated and statistically analyzed by an IBM compatible personal computer with SPSS statistical package version 23 (SPSS Inc. Released 2015. IBM SPSS statistics for windows, version 23.0, Armnok, NY: IBM Corp.).Chi-square test $\left(\chi^{2}\right)$ was used to study the correlation between qualitative variables. Two-sided $p$-value of $<0.05$ was set to be statistically significant.
Among the entire studied group constituting 13,782 individuals, the prevalence of hypertension, diabetes mellitus and obesity was reported to be $12.3 \%, 7.05 \%$ and $11.7 \%$ respectively. Districts wise, Elbagour, Tala and Shebin Elkom were ranked as the top 3 districts in Monoufia governorate regarding hypertension prevalence, which was $14.65 \%, \quad 14.34 \%$ and $14.05 \%$ respectively, followed by Berket Elsaba (12.97\%), Ashmon (12.75\%), Menouf (11.90\%) and Elshohada (10.99\%), lastly, Quesina (9.91\%), Elsadat (6.21\%) and Sers Ellian (5.57\%). Diabetes mellitus was most prevalent in Ashmon (8.97), Berket Elsaba (8.10\%), Menouf (8.12\%) and Elshohadaa (8.02\%), followed by Elbagur (7.01\%) and Tala(7.57\%) and lastly Shebin Elkom (5.36\%), Elsadat $(7.91 \%)$ and Sers Ellian (3.6\%). For obesity, it was more prevalent in Quesina (17.4\%), Sers Ellian (15.7\%) and less prevalent in EL-Bagour (7.2\%). Elbagour district showed concentration of high levels of both hypertension and diabetes while Quesna district showed high levels of the 3 of hypertension, diabetes and obesity (Table 1, Fig. 1- 3)

\section{Results:}


The studied group showed significantly higher prevalence of hypertensive cases among males, older than 40 years and those living in urban areas $(p<0.001)$ (Table 2). Diabetes mellitus had significantly higher prevalence among females older than 40 years $(\mathrm{P}<0.001)$ without association with the residential area either rural or urban $(\mathrm{P}=0.126) \quad$ (Tables 2). Obesity had significantly higher prevalence among females, older than 40 years and those of urban residence $(\mathrm{P}<0.001)$. (Tables 2)

\section{Discussion:}

Egypt is the most populated country in the Arab world. The total Egyptian population reached 100 million in February 2020 according the CAPMAS. ${ }^{(11)}$ As a part of the Mediterranean area, Egypt has an increasing burden of non-communicable diseases (NCDs) which is one of the major developmental challenges in the $21^{\text {st }}$ century. NCDs are responsible for more than $57 \%$ (2.2 millions) of all deaths in the region. Unless serious actions are taken, this number may reach 2.4 million deaths by the year 2025. ${ }^{(12)}$

The prevalence of hypertension was found to be $12.3 \%$ in this survey. A higher prevalence was observed among males and urban resident population. These results conform to the Egypt health issue survey (EHIS) 2015, which reported that around 1 in 6 women and men aged 15-59 were diagnosed as hypertensive. Age was directly correlated with the proportion who was suffering hypertension; more than $50 \%$ of women and more than 2 in 5 men in aged 55-59 were hypertensive, and $11 \%$ of women and $10 \%$ of men in same age group had a moderately or severely elevated blood pressure. Many Egyptians did not know that they have hypertension and among them, $73 \%$ of men and $47 \%$ of women were not ever told previously that their blood pressure was elevated. Hypertension was higher in urban population with $17.2 \%$ compared to rural population with $16.4 \%$. ${ }^{(13)}$

Higher prevalence of hypertension $(38.2 \%)$ was observed by Gabal et al. ${ }^{(14)}$ in a village in Menoufia governorate, and another population survey conducted by Gadalla et al. ${ }^{(15)}$ reported a prevalence of $31.2 \%$ in a slum area in Cairo, and revealed increased hypertension prevalence with increasing age. This study is more in line with the results of 
Egypt health issue survey's data and clearly showed lower rates than Gabal and colleagues. ${ }^{(14,15)}$ This may be due to different sample characteristic that was much smaller than ours.

About 422 million adults in the whole world were suffering from diabetes in 2014, compared to 108 million in 1980s. Its global prevalence has nearly doubled since 1980 from $4.7 \%$ to $8.5 \%$ in 2014. This was associated with the increased prevalence of risk factors such as overweight and obesity. Diabetes prevalence was also higher in low- and middle income countries than highincome countries. ${ }^{(16)}$ In the current work, the overall prevalence of diabetes was $7.05 \%$. It was more prevalent in female $7.8 \%$ versus $6.21 \%$ among males. Herman et al., ${ }^{(17)}$ performed a crosssectional population based survey on 6052 adults ( $\geq 20$ years) in Cairo and its rural surroundings and found the overall prevalence of diabetes was $9.35 \%$. In rural areas, $4.9 \%$ had diabetes, while $13.5 \%$ of the lower SES urban population had diabetes and $20.0 \%$ of the higher SES had diabetes.

In the year 2012, the prevalence of diabetes was $17.2 \%$ among adult
Egyptian population aged 20-79 years as reported by MOHP and FETP population bases survey. The WHO diabetes country profile in 2016 showed higher overall prevalence of diabetes $(16.2 \%)$ in the whole population, however it agreed to our study in being more prevalent in females $(18.2 \%)$ than males $(14.2 \%) .^{(18)}$ These findings interestingly indicate a significant lower prevalence of DM in Menoufia governorate for more in deep research for its underlying factors.

Regarding obesity, in this survey, the prevalence was found to be $11.7 \%$. This is higher than a prevalence of $6.5 \%$ reported by national nutritional institute according to a survey conducted in 2007. ${ }^{(19)}$ While another survey that was conducted by Health \& Pharmaceuticals, State of Health and was performed throughout the period from 2007 to 2016 revealed very different findings. It documented increasing obesity prevalence throughout the studied years from $24.6 \%$ to $31.1 \%$. $^{(20)}$

This increasing prevalence can be explained as modernization pushes towards sedentary lifestyle, the increasing rate of obesity represents one of its major outcomes as it has led to 
energy imbalance due to lack of physical activities. ${ }^{(21)}$ Egypt is considered an overurbanized country as many of its population have moved from traditional farming life to the urban modernized life. $^{(22)}$

The prevalence of obesity among females in the present study was $14.19 \%$ and among males was $10.43 \%$. These findings were much lower than a study conducted in 2005 and reported that obesity was $21.8 \%$ in males and $39 \%$ in females. ${ }^{(23)}$ Another one conducted in 2014 found that obesity in males was $21.4 \%$, while in females it was $48.5 \%$. ${ }^{(24)}$ These controversies in findings in different studies need a regular national estimate for obesity as a modifiable risk factor for upcoming non-communicable disease epidemics in Egypt.

This study showed increased prevalence of diabetes, hypertension and obesity in the middle age adults and this is in agreement with the fact that many more middle-aged people are being diagnosed with diabetes, with the rate among the 40-60 age groups doubling in the past 20 years. Obese adults are five times more likely to develop type 2 diabetes, compared to those who have healthy weight ranges.

The present study showed prevalence of obesity with age, and among females, this is in agreement with a study conducted in 2002 and highlighted the significant increase in the prevalence of obesity and overweight with age in both Saudi males and females. ${ }^{(25)}$ From our results it seemed that there was some sort of association between hypertension, diabetes and obesity in relation to age as the three parameters are more prevalent among adults aged $>40$ years. Regarding gender there is association between diabetes and obesity among females which is in agreement with a study conducted with Wang et al. ${ }^{(26)}$

Conclusion: Hypertension, diabetes and obesity were prevalent in Menoufia governorate regarding male and female gender, >40 years old age and in urban sector. There is need to extensive awareness programs for the general public, highlighting the causes, complications and how to provide control of diabetes, hypertension and obesity.

Study limitations: the relatively low response rate by the invited medical 
students and the large number of incomplete questionnaires.

Acknowledgement: All the authors would like to express their deep gratitude to the medical students and their families who participated in this work and would like to acknowledge their effort to accomplish this research.

Fund: no funding was received.

\section{References:}

1. Ibrahim MM, Albertino $\mathrm{T}$. Hypertension in developing countries. Lancet 2012; 380:611-9.

2. Shah A, Afzal M. Prevalence of diabetes and hypertension and association with various risk factors among different Muslim populations of Manipur, India" J Diabetes Metab Disord. 2013; 12: 52.

3. Mancia G, Giannattasio C. Diagnostic and therapeutic problems of isolated systolic hypertension. J

Hypertens.2015; 33:33-43.

4. Hasan DM, Emeash AH, Mustafa SB et al. Hypertension in Egypt: A Systematic Review. Curr Hypertens Rev. 2014;10(3):134-41.
5. Hegazi R, El-Gamal M, Abdel-Hady $\mathrm{N}$ et al. Epidemiology of and Risk Factors for Type 2 Diabetes in Egypt. Ann Glob Health. 2015 NovDec;81(6):814-20. doi: 10.1016/j.aogh.2015.12.011.

6. Alva ML, Gray A, Mihaylova B et al. The impact of diabetes-related complications on healthcare costs: new results from the UKPDS (UKPDS 84). Diabet Med. 2015; 32:459-66.

7. King H, Rewers M. WHO Ad Hoc Diabetes Reporting Group. Global estimates for prevalence of diabetes mellitus and impaired glucose tolerance in adults. Diabetes Care. 1993; 12:157-177. doi: 10.2337/diacare.16.1.157.

8. Sowers JR, Khoury S. Diabetes and hypertension: a review. Prim Care. 1991; 12 (3):509-24.

9. Ruilope LM, Garcia-Robles R, Morena B. Obesity, cardiovascular risk andpharmacotherapy. Blood Pressure. 2002;11: 260-262

10. Abegunde DO, Mathers CD, Adam T et al. The burden and costs of chronic diseases in low-income and middleincome countries. The Lancet. 2007; 
370(9603),

1938. doi:10.1016/s0140-

6736(07)61696-1

11. Central agency for public mobilization and statistics (CAPMAS), population clock, Available at: http://www.capmas.gov.eg/HomePag e.aspx last accessed at $06-03-2020$

12. WHO, EMERO. National multisectoral action plan for noncommunicable diseases in Egypt 2017-2022. Available at: http://www.emro.who.int/egy/egyptevents/ncds-action-plan-inegypt.html. Last access 06-28-2018. Last accessed July 2019.

13. Egypt health issue survey. 2015. Available at: https://dhsprogram.com/pubs/pdf/FR 313/FR313.pdf. Last accessed July 2019.

14. Gabal MS, Abd Elaziz KM, Mostafa NS et al. Prevalence of Hypertension and Quality of Life among Hypertensive Patients in An Egyptian Village. The Egyptian Journal of Community Medicine. 2018; 36 (2): $23-35$.
15. Gadallah M, Abdel Megid S, Mohsen A et al. Hypertension and associated cardiovascular risk factors among urban slum dwellers in Egypt: a population-based survey. Eastern Mediterranean Health Journal 2018; $\underline{24}$ (5): $232-40$

16. WHO. Global report on diabetes, 2016. Available at: https://apps.who.int/iris/bitstream/ha ndle/10665/204871/9789241565257 _eng.pdf;jsessionid=C0C1F73E9245 D9CD9B5E0C13ABA9658E?sequen ce $=1$. Last accessed February 2019.

17. Herman WH, Ali MA, Aubert RE et al. Diabetes mellitus in Egypt: risk factors and prevalence. Diabet Med. 1995; 12 (12):1126-31.

18. World health organization- diabetes country profile. 2016, Diabetes Mellitus in Egypt, Epidemiological Profile: Population Based Survey 2012, ministry of health and population (MOHP) and Field Epidemilogoy traning progtam (FETP). Available at: https://www.who.int/ncds/surveillanc e/steps/STEPS_Report_Egypt_200506.pdf. 
19. Shaheen FM, Hathout AM, Tawfik AM. National survey of obesity in Egypt. Final report, National Nutritional Institute, 2004 cited at: National Food \& Nutritional Policy Strategy (2007- 2017). Towards achievement of the Millenium Developments Goals (MDGs): National Nutritional Institute; 2007;82. Available at: https://www.unicef.org/eg_landscape _anaylsis_report_january_2013.pdf

20. Health and Pharmaceuticals, State of Health. Prevalence of obesity in the adult population aged 18 years and older in Egypt from 2007 to 2016. Available at https://www.statista.com/statistics/97 9509/egypt-prevalence-of-obesityadult-population-aged-18-years-andolder/.Last accessed 6-3 - 2020

21. World Health Organization. Obesity: preventing and managing the global epidemic. 2000 Available from: https://www.who.int/nutrition/public ations/obesity/WHO_TRS_894/en/

22. Abu-Lughod J. Urbanization in Egypt: Present State and Future
Prospects. Economic Development and Cultural Change, 13(3): 313343.http://www.who.int/ncds/surveill ance/steps/STEPS_Report_Egypt_20 05-06.pdf

23. Mowafi M, Khadr Z, Kawachi I et al. Socioeconomic status and obesity in Cairo, Egypt: A heavy burden for all. J Epidemiol Glob Health. 2014 Mar;4(1):13-21. doi: 10.1016/j.jegh.2013.09.001. Epub 2013 Oct 16.

24. Galal OM. The nutrition transition in Egypt: obesity, undernutrition and the food consumption context. Public Health Nutr.2002;5 (A) ; 141-148.

25. El-Hazmi MAF, Warsy AS. Relationship between Age and the Prevalence of Obesity and Overweight in Saudi Population. Bahrain Medical Bulletin. 2002; 24 : (2)

26. Wang S, Ma W, Yuan $\mathrm{Z}$ et al. Association between obesity indices and type 2 diabetes mellitus among middle-aged and elderly people in Jinan, China: a cross-sectional study. BMJ Open. 2016; 6(11): e012742. 
Table (1): Prevalence of hypertension, diabetes and obesity in different districts of Menoufia governorate

\begin{tabular}{|l|c|c|c|c|c|c|c|}
\hline $\begin{array}{l}\text { Menoufia } \\
\text { Governorate } \\
\text { Districts(no.=10) }\end{array}$ & $\begin{array}{l}\text { Total studied } \\
\text { population } \\
\text { (No.=13782) }\end{array}$ & \multicolumn{2}{l|}{ Hypertension } & \multicolumn{2}{l|}{$\begin{array}{l}\text { Diabetes } \\
\text { Mellitus }\end{array}$} & \multicolumn{2}{l}{ Obesity } \\
\cline { 3 - 8 } & No & $\%$ & No & $\%$ & No & $\%$ \\
\hline - Shebin Elkom & $2762(20.0)$ & 388 & 14.05 & 148 & 5.36 & 353 & 12.8 \\
\hline - El bagour & $1470(10.7)$ & 214 & 14.56 & 103 & 7.01 & 106 & 7.20 \\
\hline - Tala & $1624(11.8)$ & 233 & 14.34 & 123 & 7.57 & 208 & 12.8 \\
\hline - Ashmon & $1450(10.5)$ & 185 & 12.75 & 130 & 8.97 & 162 & 11.20 \\
\hline - Berket Elsaba & $1395(10.1)$ & 181 & 12.97 & 113 & 8.10 & 130 & 9.30 \\
\hline - Quesina & $1442(10.5)$ & 143 & 9.91 & 102 & 7.07 & 251 & 17.4 \\
\hline - Menouf & $997(7.2)$ & 119 & 11.90 & 81 & 8.12 & 118 & 11.8 \\
\hline - Sers Ellian & $305(2.2)$ & 17 & 5.57 & 11 & 3.60 & 48 & 15.7 \\
\hline - Al shohada & $1483(10.8)$ & 163 & 10.99 & 119 & 8.02 & 147 & 9.90 \\
\hline - El sadat & $854(6.2)$ & 53 & 6.21 & 42 & 4.91 & 87 & 10.20 \\
\hline Total & 13782 & 1696 & 12.30 & 972 & 7.05 & 1610 & 11.70 \\
\hline & & & & & & & \\
\hline
\end{tabular}


Table (2): Risk factors associated with hypertension, diabetes and obesity among the studied group:

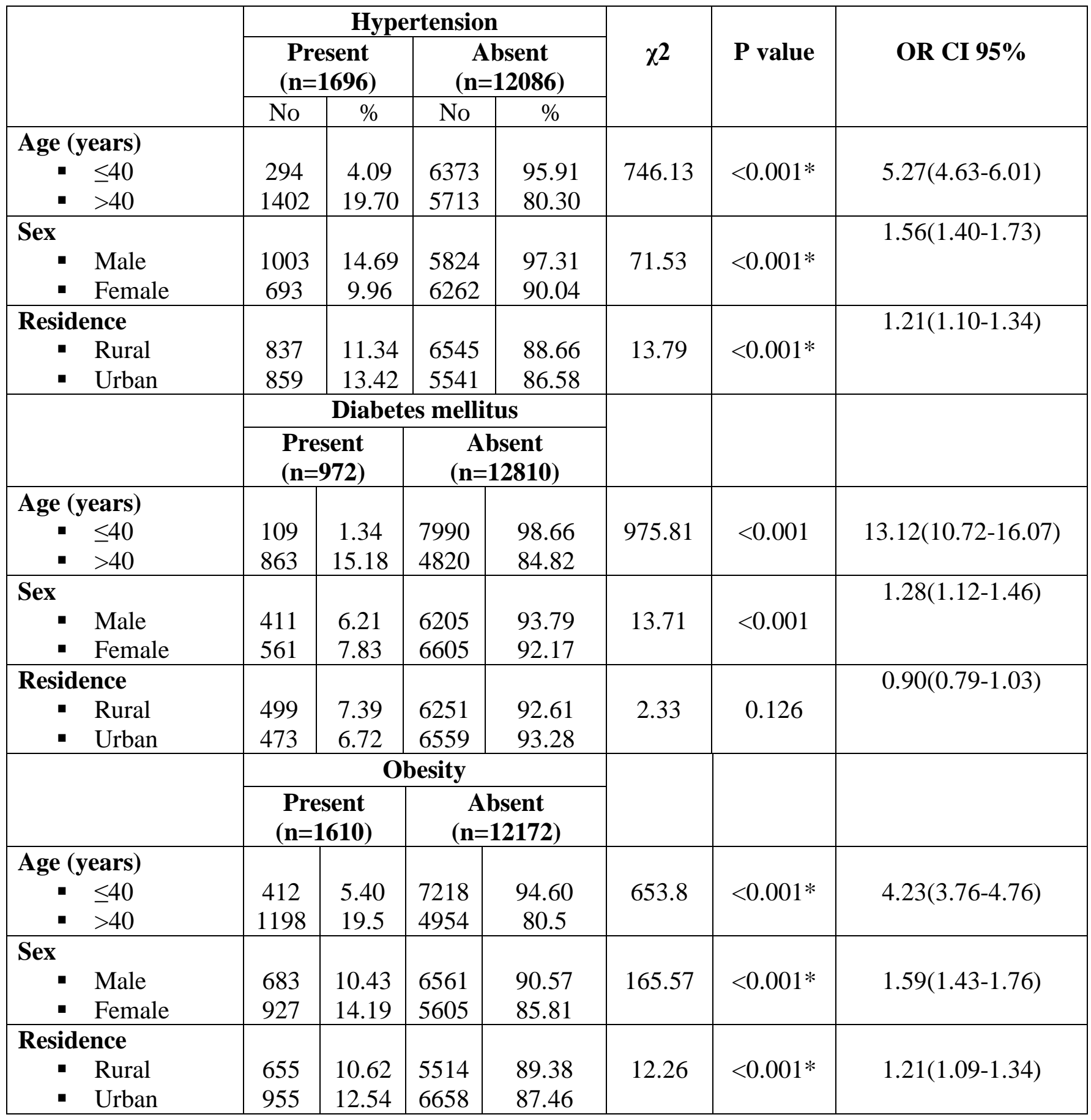

*Statistically Significant 


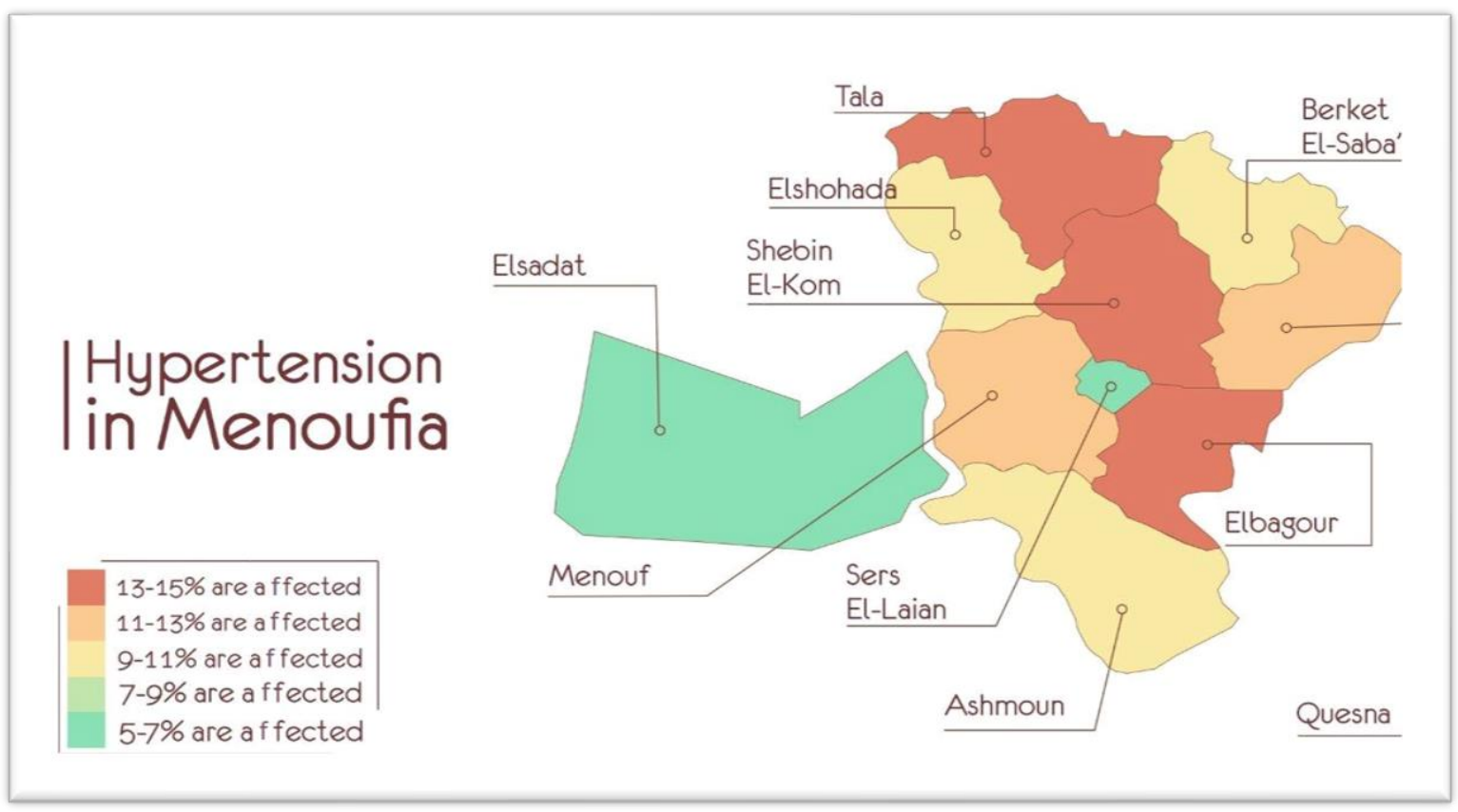

Fig (1): Mapping of hypertension in Menoufia governorate

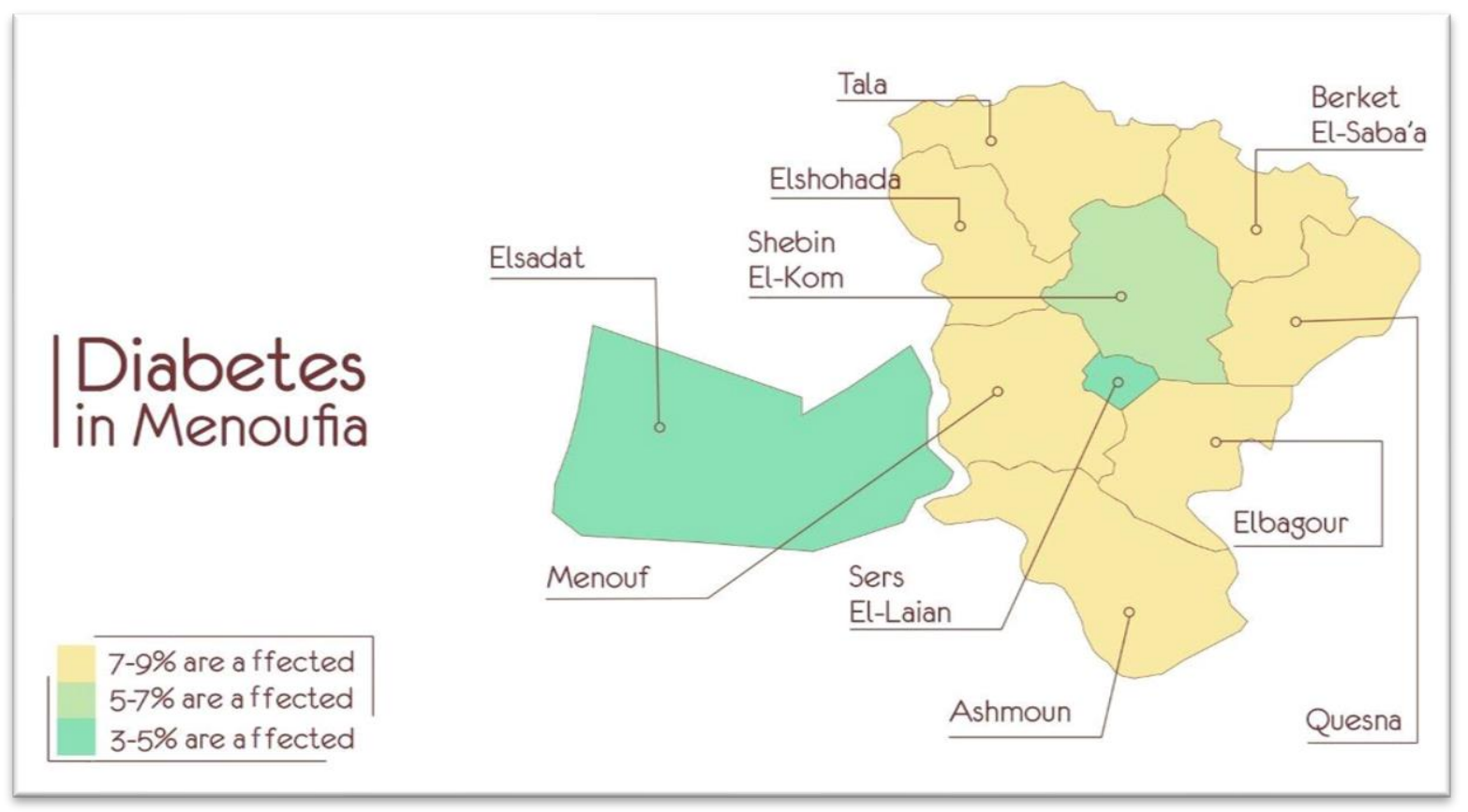

Fig (2): Mapping of diabetes mellitus in Menoufia governorate 


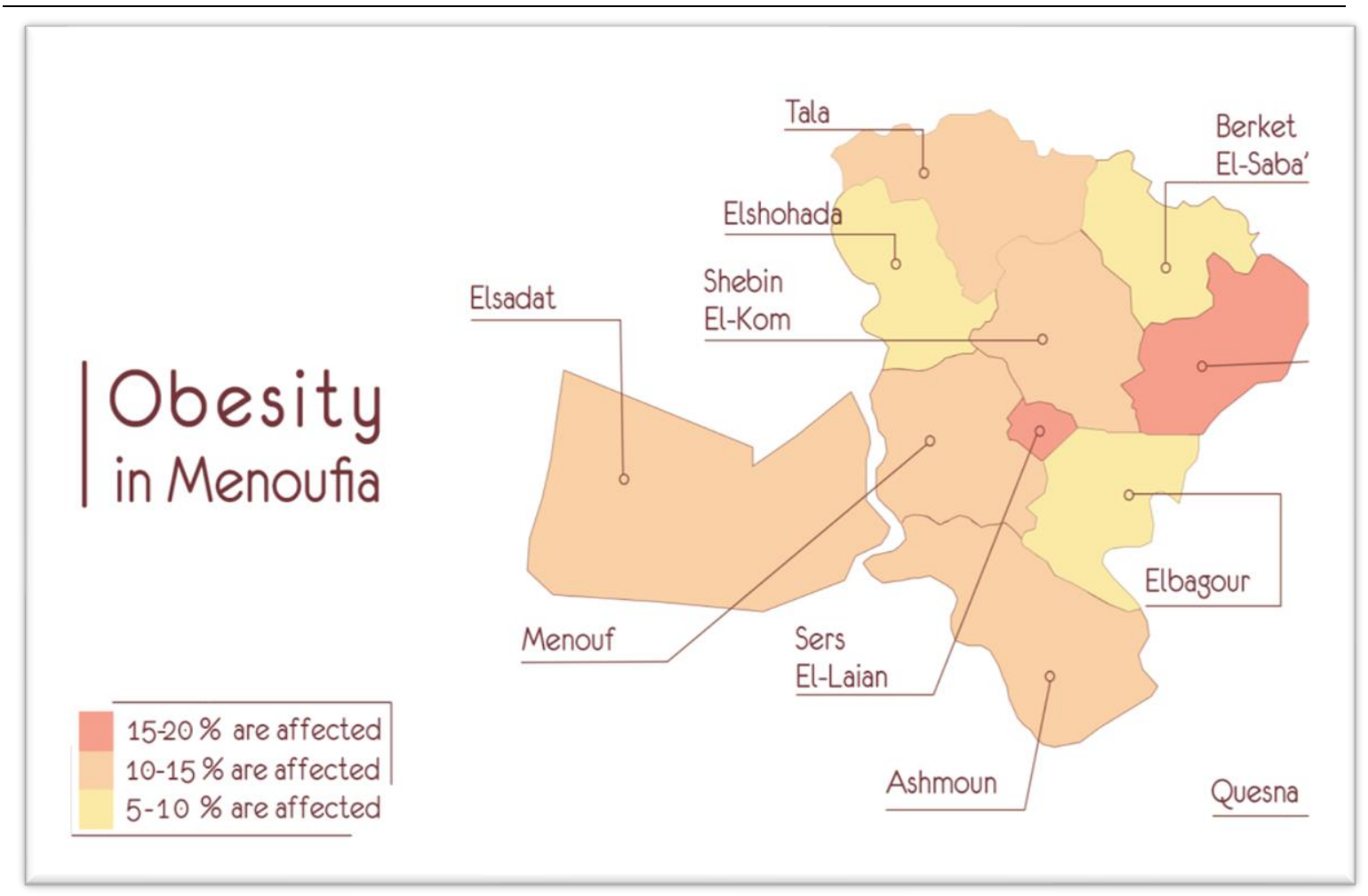

Fig (3): Mapping of obesity in Menoufia governorate 


\section{الملخص العربي \\ الخريطة الوبائية لارتفاع ضغط الدم والبوال السكري والسمنة لاى أفراد أسر طلاب كلية الطب ـ

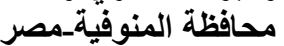 \\ هالة مروان - رضا عبداللطيف الغمرينى - زينب عبدالعزيز قاسم - شيماء شريف سليمان}

الخلفيه العلميه:أوضحت الدراسات السابقة أن ارتفاع ضغط الدم (HT) داء السكري من النوع الثاني وأيضا السمنة تعد من الأمر اض المزمنة غير المعدية وهي الأكثر شيوعا في كل من البلان النامية وكذلك المتقدمة وتثكل عبءً اقتصاديا هائلا على منى

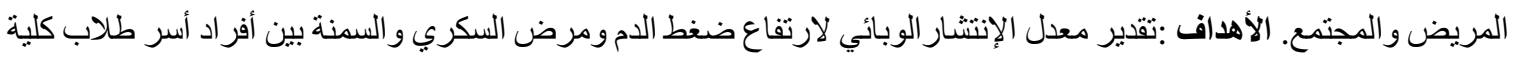
الطب بالمنوفية. منهجيه البحث :در اسة مقطعية شملت 13782 من أفر اد أسر مجموعة من طلاب كلية الطب ، جامعة المنوفية.

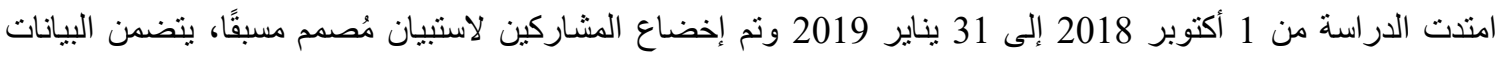

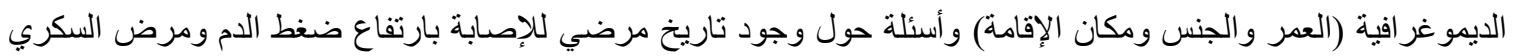
و السمنة بين أفراد الأسرة للطلاب المشاركين البالغين (فوق سن 18 سنة). النتائج :كانت معدلات انتشار ارتفاع ضغط الدام و السكري والسمنة 12,3 ٪ ، 7,05 ٪ و 11,7 ٪ بالترتيب. كانت الاصابة بارتفاع ضغط الدم أكثر انتشارًا بين الذكور، الذين تزيد أعمار هم عن 40 عامًا و الذين يعيشون في المناطق الحضرية، في حين كان مرض السكري أكثر انتشارًا بين الإناث، و الذين

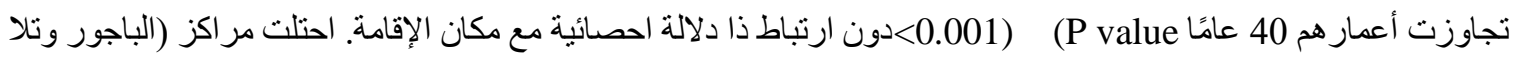

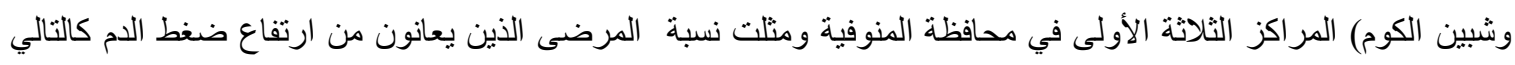

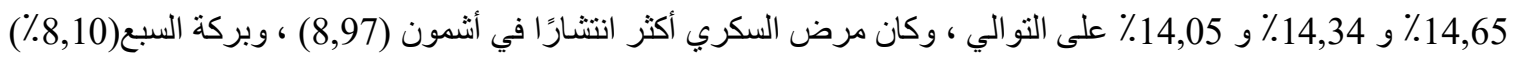

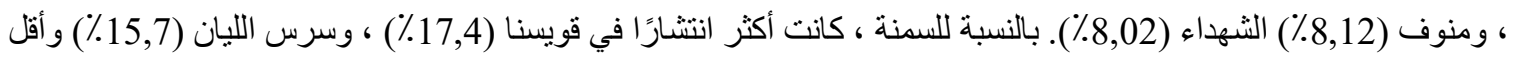

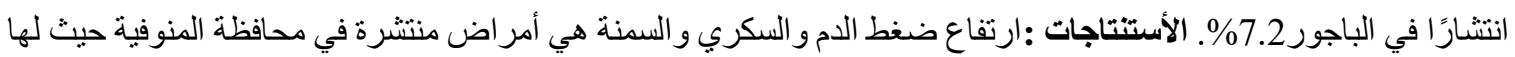
ارتباطات دالة إحصائيا بنوع الجنس من الذكور و الإناث ، و الذين تزيد أعمار هم عن 40 عامًا وفي القطاع الحضري. 